\title{
THE EFFICIENCY OF APPLICATION OF MINERAL FERTILIZERS IN COMBINATION WITH THE MICROBIAL PREPARATIONS AT GROWING OF SPRING BARLEY
}

\author{
T. M. Hryhorieva
}

\author{
Kirovohrad State Agricultural Experimental Station of NAAS \\ 2, Tsentralna Str., vil. Sozonivka, Kirovohrad district, Kirovohrad region, 27602, Ukraine; \\ e-mail: tanyusha-grigorieva@mail.ru
}

Increased production of high-quality grain of spring grain crops and its sustainable use is one of the main tasks of modern agriculture of Ukraine. The basis of the formation of high yields, in addition to the genetic potential of plants, is created by the technology of growing crops. Traditional technological factors include the use of high doses of mineral fertilizers, crop protection chemicals from diseases, pests and segetal plants. These measures let significantly increase yields and save the crops, but at the same time have side effect: contamination of soil and ground water, reducing of soil fertility, destruction of beneficial insects that does not contribute to ensuring the sustainability of agro-ecosystems [1]. In this regard, the elements of new technologies are developed that involve the use of microbial preparations. They are safe preparations, biological agents of which are capable of fixing atmospheric nitrogen, soil phosphate transformation, production of amino acids and other physiologically active compounds [2-4].

An important argument in favour of biological preparations use is that they have relatively low cost, but their effectiveness is largely dependent on weather conditions and of farming culture [5]. A special factor that can influence the efficiency manifestation of microbial preparations is the level of mineral fertilizers application.

The goal of the research was to study the efficacy of microbial preparations use on growth, development, productivity and quality indicators of grain of spring barley on different backgrounds of mineral nutrition. The possibility of combining microbial preparations with plant growth and development stimulants was also investigated.

Materials and methods. The study was conducted during 2011-2013 in the laboratory of agriculture of Kirovohrad State Agricultural Experimental Station of NAAS.

Soil of the experimental plot ordinary black soil, hard loamy medium humic (humus content $-4.69 \% \mathrm{pH}_{\text {sal. }}$ 5.9).

Spring barley of Sozonivskiy variety was sown in the experiment. Precursor -grain corn. Area of the record plot $45.9 \mathrm{~m}^{2}$. Repetition - quadruple.

Seed treatment with microbial preparation was done on the day of planting. Crops sprinkling was conducted with growth regulator in the phase of tillering. Fertilizers were applied in the form of Nitroammophoska in autumn under ploughing.

Experiment was two-factor:

factor $A$ - nutrient status:

1. Without fertilizers;

2. $\mathrm{N}_{20} \mathrm{P}_{20} \mathrm{~K}_{20}$;

3. $\mathrm{N}_{40} \mathrm{P}_{40} \mathrm{~K}_{40}$;

Factor $B$ - biological preparations:

1. Without treatment;

2. Microhumin, 200 grams per hectare seed rate;

3. Microhumin, 200 grams per hectare seed rate + plant growth regulator (PGR) Biolan, $20 \mathrm{ml} / \mathrm{ha}$;

4. Phosphoenterin, $100 \mathrm{ml}$ per hectare seed rate;

5. Phosphoenterin, $100 \mathrm{ml}$ per hectare seed rate + Biolan $20 \mathrm{ml} / \mathrm{ha}$.

Microhumin - free running, homogenous wet mass of dark brown colour. The preparation consists of a specially prepared peat containing reproduced bacteria of Azospirillum genus. Also it contains physiologically active substance of biological origin, microelements in chelated form and macroelements. Biological preparation provides increase in field germination and viability, promotes the developed of root system and active plant-bacterial associations, 
intensifies the process of photosynthesis in plants. The preparation increases plant resistance to diseases, both by improving the immune status, and because of the content of substances of fungistatic action. 200 grams of the preparation is consumed per one hectare rate [6].

Phosphoenterin - biological preparation based on Enterobacter nimipressuralis bacteria, which mobilize hard-to-get phosphates, transforming them into the form available for assimilation by plants. Increases the coefficients of the use of active substance from phosphate fertilizers. Recommended for grain, legumes and vegetable crops. Preparation dose $-100 \mathrm{ml}$ per hectare seed rate. [7]

Biolan - highly effective biological regulator of broad-spectrum activity (Agroemistim-extra). Allowed for seed treatment and sprinkling of grain crops, grain legumes, technical and forage crops, vegetables, gourds, grapes, fruits and berries. Biolan promotes the acceleration of cell division, root development, increase of leaf surface and chlorophyll content, reduces the phytotoxic action of pesticides, has antimutagenic effect, improves the quality of grown products, and increases the productivity of crops. $20 \mathrm{ml}$ is consumed per
1 ton of seeds, $10-20 \mathrm{ml}$ - per 1 ha depending on the crop and agricultural background level. [8]

Spring barley was sown with seeding machine $\mathrm{CPH}-3,6$ at the rate of 4.5 million pcs/ha. Harvesting was carried out by combine harvester "Sampo-130".

When conducting the study we were guided by conventional methods $[9 ; 10]$ and recommendations on the effective application of microbial preparations [11].

So, the use of microbial preparations for pre-sowing inoculation of spring barley seeds both separately and in the combination with PGR Biolan positively influenced the productivity and quality both on natural background and at fertilizer application. When growing spring barley in the conditions of northern Steppe of Ukraine the fertilization by mineral fertilizers at the dose of $\mathrm{N}_{20} \mathrm{P}_{20} \mathrm{~K}_{20}$ and $\mathrm{N}_{40} \mathrm{P}_{40} \mathrm{~K}_{40}$ was unprofitable and production costs were not compensated by crops yield because of high prices for them.

Economically justified is the use of microbial preparations on natural background (without fertilizers), which gives the opportunity to get additional 214-431 $\mathrm{UAH} / \mathrm{ha}$ at the additional costs return level of 2.89-446 UAH/UAH. 